UDC 343.1

DOI https://doi.org/10.32849/2663-5313/2021.7.14

\title{
Oleh Tarasenko,
}

PhD in Law, Associate Professor, Associate Professor at the Department of Operational and Investigative Activities, National Academy of Internal Affairs, 1, Solomianska square, Kyiv, Ukraine, postal code 03035, OlehTarasenko@ukr.net

ORCID: orcid.org/0000-0002-3179-0143

\section{Oleksandr Striltsiv,}

PhD in Law, Senior Researcher, Commissioner for Anti-Corruption Activities, National Academy of Internal Affairs, 1, Solomianska square, Kyiv, Ukraine, postal code 03035, OleksandrStriltsiv@ukr.net ORCID: orcid.org/0000-0002-8324-3053

Tarasenko, Oleh, Striltsiv, Oleksandr (2021). The need for legal regulation of the introduction of computer intervention as a new investigative measure of operational units. Entrepreneurship, Economy and Law, 7, 90-97.

\section{THE NEED FOR LEGAL REGULATION OF THE INTRODUCTION OF COMPUTER INTERVENTION AS A NEW INVESTIGATIVE MEASURE OF OPERATIONAL UNITS}

Abstract. The relevance of the article is determined by the spread of crime on the Internet, which is the most dynamic group of socially dangerous acts, the most advanced in both the world and Ukraine, and gaining the most dangerous momentum. This is caused by the spread of automation, informatization and computerization of all sectors of life, the development of science, the rapid expansion of information technologies. Moreover, negative aspects are increasing, for example, information technologies are used for unlawful purposes, as a result, qualitative and quantitative changes occur in cybercrime, which is now more professional, organized and sophisticated. Results. The article reveals the lack of statutory powers of the operational units of the National Police to perform missions regarding detection and prevention of criminal offenses committed on the Internet, including stopping the spread and termination of prohibited and restricted content, as well as recording the traces in case of commission of a criminal offense. Conclusions. The determined means of termination and restricting of the prohibited or restricted content in social media and video hosting permits concluding that a new investigative measure, such as a computer intervention, is required. The authors make proposals to the Law of Ukraine "On Operational and Investigative Activities" regarding the regulatory mechanism for the suggested new investigative measure. It is underlined that the above measures shall be carried out by operational units of the National Police of Ukraine without the decryption of account and the IP address affiliation to the law enforcement agency or persons working in it. It is concluded that currently no defined grounds exist in the legal regulations to stop the distribution and termination of prohibited content, including by operational units. This deters law enforcement agencies from legal activities aimed at preventing and combating criminal offenses committed on the Internet. Therefore, it is proposed to introduce an investigative measure such as a computer intervention, thanks to which operational units of the National Police of Ukraine can carry out measures on covert detection, prevention of criminal offense, and also to record the traces in case of its commission.

Key words: computer intervention, investigative measure, prohibited content, operational units, criminal offenses, Internet.

\section{Introduction}

The relevance of the topic. The spread of crime on the Internet is the most dynamic group of socially dangerous acts, the most advanced both in the world and Ukraine, and gaining the most dangerous momentum. This is caused by the spread of automation, informatization and computerization of all sectors of life, the development of science, the rapid expansion of information technologies.

Moreover, negative aspects are growing, for example, information technologies are used for unlawful purposes, as a result, qualitative and quantitative changes occur in cybercrime, which is now more professional, organized and sophisticated. For example, in 2020, more 
than 33 thousand appeals (messages) of citizens concerning fraudulent actions against them on the Internet were submitted to cyber police units of the National Police of Ukraine (Official site of the Cyberpolice of Ukraine, 2021) and according to the Ukrainian Interbank Association of Members of EMA Payment Systems (Official site of the Ukrainian Interbank Association of Members of EMA Payment Systems, 2021), the Internet-network permitted fraudsters to "earn" UAH 252 million only in our country. Illegal activities promote the spread of prohibited or restricted content (hereinafter - prohibited content) on the Internet, which, according to O.M. Striltsiv, Yu.Yu. Orlov, V.V. Kryzhna, O.V. Maksymenko (Striltsiv, Kryzhna, Maksymenko, 2014), can be used in the following areas:

a) illegal purchase and/or sale of items and substances prohibited for free circulation:

- illegal purchase and/or sale of items and substances prohibited for free circulation (illegal purchase of firearms, ammunition or explosives (art. 263 of the CC of Ukraine); purchase of radioactive materials (art. 265 of the CC of Ukraine); illegal purchase or sale of narcotic drugs, psychotropic substances or their analogues (art. 307 of the CC of Ukraine); illegal purchase, transfer or sale of equipment for the manufacture of narcotic drugs, psychotropic substances or their analogues (art. 313 of the CC of Ukraine); sale of forged documents for obtaining narcotic drugs, psychotropic substances or precursors (art. 318 of the CC of Ukraine); illegal purchase or sale of poisonous or potent substances or poisonous or potent drugs (art. 321 of the CC of Ukraine); sale of counterfeit medicines (art. $321^{1}$ of the CC of Ukraine);

b) placement on the Internet of prohibited information about:

- state or other secret protected by law: espionage (art. 114 of the CC of Ukraine), a hospital secret (art. 145 of the CC of Ukraine), secret ballot (art. 159 of the CC of Ukraine), the secret of adoption (art. 168 of the CC of Ukraine), commercial secret (art. 232 of the CC of Ukraine), State secrets (art. 328 of the CC of Ukraine), with limited access, stored in electronic computing machines (computers), automated systems, computer networks or on the media (art. $361^{2}$ of the CC of Ukraine), safety measures concerning the person taken under protection (art. 381 of the CC of Ukraine), the data of pre-trial investigation and inquiry (art. 387 of the CC of Ukraine), the information of military nature, which is the state secret (art. 422 of the CC of Ukraine);

- fraudulent reports on threats to the security of citizens, on destruction or damage to property (art. 259 of the CC of Ukraine), calls for actions aimed at violent change or overthrowing the constitutional order, or for seizure of the State power (art. 109 of the CC of Ukraine), calls for actions that threaten public order (art. 295 the CC of Ukraine);

- pornographic objects and images (art. 301 of the CC of Ukraine); works promoting the cult of violence and cruelty, racial, national or religious intolerance and discrimination (art. 300 of the CC of Ukraine);

- violations of the equality of citizens depending on their race, nationality, religious beliefs, disability and other characteristics (art. 161 of the CC of Ukraine) (Striltsiv, Kryzhna, Maksymenko, 2014).

Basic material statement. The analysis of the practice of the operational units of the National Police against the spread of prohibited content permits stating that the objects of the most common placement of such content are social media Instagram and Telegram. This is due to the fact that these networks facilitate to create large groups, to provide personal communication in private chat with certain participants by means of moderation, to register under any name (ausername), tosearchforapersonbyausername, to guarantee confidentiality of communication, such as non-displayed phone number, to redirect video and photo content, to use the functions of self-destruction of the message after its reading by the interlocutor, as well as the functions of self-destruction of the account, if it has not been used during the chosen period (1 month, 3 months, half year, year).

Such social media as Facebook, Twitter and YouTube video hosting are used for illegal purposes most rarely. This is due to the stricter policy of their administrators for the content circulation.

Regarding social media such as VK (Vkontakte) and OK (Odnoklassniki), Ukraine has restrictions on their application in accordance with the Decree of the President of Ukraine № 133/2017 of May 17, 2017 (On the application of personal, special, economic and other restrictive measures (sanctions), 2017).

However, Ukrainian legislation does not even empower either law enforcement agencies, or operators and telecommunication providers who provide Internet access services, to perform actions on limitation, termination of granting or prohibition of providing telecommunication services and use of telecommunication networks of public use in case of detection of prohibited content. Only clause 9 of part 1 of Article 38 of the Law of Ukraine "On Telecommunications" (On Telecommunications, 2003) adds 
to the rights of operators, providers of telecommunications an opportunity to disconnect them, on the basis of the decision of the court, from final equipment, if it is used by the Subscriber for illegal actions or actions threatening the interests of State security. According to paragraph 18 of part 1 of article 39 the above-mentioned Law, the responsibilities of telecommunications operators and providers providing Internet access services include to restrict access, on the grounds of the court's decision, of its subscribers to resources through which child pornography is distributed.

\section{Activities of the National Police} of Ukraine

Legal regulations on the activities of the National Police of Ukraine do not grant its units with the rights and powers to remove or prevent access to prohibited content. Only paragraph 3 of part 1 of Article 25 of the Law of Ukraine "On the National Police" (On the National Police, 2015), among the powers of the police in the field of information and analytical support, indicates that the police "carries out information and search work, information and analytical work". However, the legislation does not provide for what further to do with the revealed information. Similarly, the Law of Ukraine "On operational and investigative activities" of 18 February 1992 № 2135-XII (On operational and investigative activities, 1992) lacks the rights and powers of operational police units aimed at removing or preventing access to content.

The analysis of other legal regulations on the procedure of removal or making access to content placed on the Internet impossible proves that only article $52^{1}$ of the Law of Ukraine "On Copyright and Related Rights" (On Copyright and Related Rights, 1993) defines the procedure for termination and prevention of infringement of copyright and/or related rights by using of audio-visual works, music works, computer programs, video fences, phonograms, programs of broadcasting on the Internet. However, according to the Law, only the copyright proprietor is granted with this right to contact the owner of the web-site (web page) through a lawyer with the application to terminate copyright infringement and/or related rights on the Internet or local network, and, accordingly, employees of operational units of the National Police of Ukraine in case of copyright infringement cannot personally require the owners of a web-site, multi-regional platform, local network, server to remove or make access impossible to electronic (digital) information that violates copyright and/ or related rights, or to hyperlink to such information on the Internet or local network.
Even restricting of access to resources on the Internet and prohibiting of the distribution of the content provided by established individuals or entities, using the provisions of paragraph 9 of part 1 of article 4 of the Law of Ukraine "On sanctions” № 1644VII (On Sanctions, 2014), may be applied only to individuals and legal entities for "limiting or stopping the provision of telecommunication services and the use of telecommunication networks of public use". Moreover, the grounds to apply these sanctions are:

1) the actions of a foreign state, a foreign legal or natural person, other entities that create real and/or potential threats to national interests, national security, sovereignty and territorial integrity of Ukraine, promote terrorist activity and/or violate human and civil rights and freedoms, the interests of society and the State, result in the occupation of territory, exportation or limitation of ownership, property loss, deterrence of sustainable economic development, full realization of rights and freedoms by citizens of Ukraine;

2) Resolutions of the General Assembly and the United Nations Security Council;

3) Decisions and Regulations of the Council of the European Union;

4) violations of the Universal Declaration of Human Rights, the United Nations Charter;

5) commission by a foreign State, a foreign legal entity, a legal entity that is under the control of a foreign legal entity or a non-resident individual, a foreigner, a stateless person, as well as terrorist actors, acts referred to in paragraph 1 in relation to another foreign State, citizens or legal entities of the latter.

Thus, operational units of the National Police of Ukraine have no legally defined rights to remove or prevent access to such prohibited content.

However, the study of the policy on functioning of social media, rules and conditions of their use enable to form the following areas of activities of operational units of the National Police of Ukraine for prevention and counteraction of criminal offenses of this scope, in accordance with the regulations and rules developed for such cases by social media and video hosting.

3. Remove or prevent access to the content of certain social media and video hosting

We will focus on ways to remove or prevent access to the content of certain social media and video hosting, which can be introduced by operational units of the National Police of Ukraine.

"Telegram". The reason for removal or denying access to the prohibited content of the social media "Telegram" 
(https://telegramfag.ru/kak-pozhalovatsya-vtelegramme)isdisseminationofinformationabout drug sales, pornography, and violence. Taking into account the specificities of the software of this social media, specialists of the cyber police faculty of Kharkiv National University of Internal Affairs have developed an instrument for termination of telegram channels used for illegal sale of narcotic drugs, psychotropic substances and precursors, namely free chat-bot in the messenger of Telegram "StopNarkotik I Mriya" (https://t.me/stopdrugsbot). The purpose of creating a chat-bot "StopNarkotik I Mriya" is to provide assistance in uniting the efforts of citizens in terminating electronic addresses of users, bots and chats, which are used by criminals to promote the use of narcotic drugs and psychotropic substances and their illegal sale.

From the moment of presentation on September 19, 2019 till March 2021, more than 30 thousand people, users of Telegram, have seen the chat-bot, of which 3,6 thousand users have expressed desire to regularly help terminate e-mail addresses of sellers of narcotic drugs and psychotropic substances. As of March 2021, during the chat-bot period, users sent to check: 4769 images; 7318 addresses at Telegram; 1600 web-site addresses. To date, 214 addresses at Telegram, which were used by criminals for the illegal distribution of narcotic drugs, psychotropic substances and precursors, including six operating in temporarily occupied territory of Donetsk and Luhansk regions, have been terminated with the help of citizens (Website of the Multimedia Platform of Foreign Broadcasting of Ukraine "Ukrinform", 2020).

Chat bot "StopNarkotik I Mriya" is able:

1) to receive from concerned citizens:

- photos of "graffiti" (inscriptions) which mark usernames (so-called Internet link) at "Telegram", through which illicit sale of narcotic drugs, psychotropic substances and precursors is carried out, with indication of GPS-coordinates or physical address where they have been found;

- addresses at Telegram messenger and websites through which illicit sales of narcotic drugs, psychotropic substances and precursors are carried out;

- addresses of places of illegal sale of narcotic drugs, psychotropic substances and precursors in inhabited localities;

2) to involve citizens in:

- termination of the address in Telegram messenger by sending complaints to the administration of the messenger with information about the addresses through which illicit sale of narcotic drugs, psychotropic substances and precursors is carried out;
- deactivation (colouring) of "graffiti" (inscriptions) with a username in "Telegram", through which illicit sale of narcotic drugs, psychotropic substances and precursors is carried out.

Chat bot offers newcomers to read the instruction before beginning the interaction, which requires to select the operating system on which Telegram is installed. The menu provides an opportunity to disable the address in Telegram, where the instruction can be used to complain about the Internet address where drugs may be sold. The "Statistics" link enables to get the numbers regarding the addresses that is terminated, the number of users, and so on.

There is also a function of "Add a Store", where you can use the instruction to report the real place of illicit sale of narcotic drugs, psychotropic substances and precursors in a certain locality, or a separate site, which is involved in such illegal activities.

Then the positive experience of using the chat-bot "StopNarkotik I Mriya" in prevention of illegal drug trafficking, promoted its use in other areas, in particular: termination of the e-mail address, which were used to commit other crimes: for the alleged sale of forged banknotes of Ukraine of various nominal value; the use of confidential information for unauthorized withdrawal of funds from bank payment cards through fake chat-bots of the State bank; placement of fake news and messages on behalf of public institutions, political figures, well-known public figures; dissemination of false and confidential information about women and others (Website of the Ministry of Internal Affairs of Ukraine, 2020).

Instagram. Employees of the social media Instagram in case of violation of the official rules and conditions of use of this social media established by developers and managers of this social media, shall have the right to terminate the content through the support service. The grounds that allow employees of operational units of the National Police of Ukraine to create complaints for negligent account holders are:

- copyright infringement: use of logos and symbols of famous brands, other people's photos and texts (all images uploaded to the user account must be either his/her or permitted by the author). If a user wants to share a someone else's picture, he/she must mark the author in the photo (provided he/she has an account on Instagram) and write his/ her name in the description. If the user uses the image for commercial purposes, he/she will need to obtain permission from the author (Site "Mydovidka", https://mydovidka.com/ instagram/yak-napisati-v-instagram-skarguyak-poskarzhitisya-na-foto-i-profil-shhob- 
jogo-zablokuvali-skilki-potribno-skarg-shhobzablokuvali);

- publication of an image and video of obscene content (erotica, pornography, violence, propaganda of anorexia, suicide, manifestation of hatred and aggression, intolerance (racism, homophobia and sexism), promotion of illicit sale of firearms and narcotic drugs, psychotropic substances and precursors, as well as photos of such substances, etc.);

- placement of obscene vocabulary, insults, threats, etc.;

- sending a spam about the offers to become a participant of financial operations or to get a free product or discount;

- the user of social media under 13 years (according to the rules of social media, to registration and to publish content can only users who is already 13 years old);

- the personal account has been broken by frauds without possibility of recovery;

- the page publishes personal and confidential information about other users;

- different IP addresses and devices

(Site "Kagutech", https://ukr.kagutech. com/3897557-blocked-account-inquotinstagramquot-the-reasons-ways-tounlock; Site "Mydovidka", https://mydovidka. com/instagram/yak-poskarzhitisya-nastorinku-v-instagrame-shhob-zablokuvalinazavzhdihttps://mydovidka.com/instagram/ yak-poskarzhitisya-na-storinku-v-instagrameshhob-zablokuvali-nazavzhdi).

There are three types of account lockout on Instagram:

- permanent (account will be disabled forever);

- temporary (account can be terminated for 24 hours), as a rule is used to prohibit messages from a subscriber, the holder of the account cannot leave the likes, add comments, post a photo caption and send the direct message.

- partially temporary (the account may be terminated from 3 to 24 hours or certain restrictions are imposed, for example, the ban to monitor several users).

The number of complaints that lead to the account termination or sanctions on Instagram is ten. The temporary warning termination of the account takes place after the first complaint on the user page. However, all applications should have grounds, such as: an example from publications, descriptions or comments, preferably in addition to the complaint to attach a screenshot of the factual violation. A complaint regarding a photo can be submitted via a special form on the website www.help.instagram.com or via a mobile application. In order to lock a person who is not in the subscription or in the subscribers, one should find the page through the search. This requires a nickname typed in a string or use a URL. When you move to someone else's profile, you need to do the same as with a friendly page. As a rule, technical support responds within one day to complaints (Sait "Vidpoviday.com", http://vidpoviday.com/ iak-zablokuvaty-chuzhyj-instagram-akkauntcherez-telefon-abo-kompiuter; Sait "Instahelper", https://insta-helper.com/ua/jakposkarzhitisja-na-akkaunt-v-instagram-i-jak/).

YouTube. This video hosting has imposed very strict requirements on content placed on channels and user accounts, which must comply with the rules of this community and terms of use. For example, the grounds for termination of a channel or account by employees of operational units of the National Police of Ukraine may be repeated violation of community rules or conditions of use in connection with placement of unacceptable content, which includes:

- offensive, hateful and/or aggressive videos or comments;

- video with explicit sexual content with minors and content that sexually exploited minors; depiction of genitals, breasts or buttocks (dressed or not dressed) for the purpose of sexual pleasure; pornography or images of sexual acts, sex organs or fetishes for sexual gratification on any surface (such as video, text, audio, images) (Sait "Youtube", https://www.youtube.com/ howyoutubeworks /policies/communityguidelines/\#community-guidelines);

- creating a channel that copies a profile, background, or general appearance of another channel in a way that makes it similar to another channel;

- impersonation: the content that looks, as if someone else publishes it, as well as the channel settings, using the name and image of a certain person, and then pretending that the person publishes the content on the channel or posting comments on other channels from that person;

- offering of monetary gifts, "get-rich-quick" schemes or pyramid schemes (sending of money without material product in the pyramid structure);

- misleading voters about the time, place, means or eligibility requirements for voting, or false claims that could materially discourage voting;

- interference with democratic processes, for example, obstructing or interrupting voting procedures;

- distribution of false information, the disclosure of which may interfere with democratic processes, such as elections;

- the content that features prolonged name calling or malicious insults (such as 
racial slurs) based on someone's intrinsic attributes, challenges that pose an imminent risk of physical injury; pranks that lead victims to fear imminent serious physical danger, or that create serious emotional distress in minors instructions to kill or harm (for example, giving instructions to build a bomb meant to injure or kill others); abuse and creation of drugs that can (mostly) lead to physical addiction; promoting or glorification of violent tragedies such as school shootings; showing how to steal tangible goods or promoting dishonest behaviour; demonstrating how to use computers or information technology with the intent to steal credentials, compromise personal data or cause serious harm to others, for example (but not limited to) hacking into social media accounts how to use apps, websites, or other information technology to gain unauthorized free access to audio content, audiovisual content, full video games, software, or streaming services that normally require payment; promoting dangerous remedies or cures;

- content promoting violence or hatred against individuals or groups based on any of the following attributes: age, caste, disability, ethnicity, gender identity and expression, nationality, race, immigration status, religion, sex, sexual orientation, veteran status;

- violent or gory content intended to shock or disgust viewers, or content that encourages others to commit violent acts, such as minor fights, terrorist attacks, street fights, physical attacks, sexual assaults, immolation, tortures, corpses, protest or riots, robbery, medical procedures or other similar scenarios;

- the content if it aims to directly sell, link to, or facilitate access to any of certain regulated goods and services listed below: alcohol, bank account passwords, stolen credit cards or other financial information; counterfeit documents or currency; controlled narcotics and other drugs; explosives, organs, endangered species, or parts of endangered species, firearms and certain firearms accessories, nicotine, including products of vaping, gambling sites on the Internet, not yet reviewed by Google or YouTube, pharmaceuticals without a prescription, sex or escort services, unlicensed medical services, human smuggling;

- the content related to the sale of firearms and accessories to it, as well as instructions how to assemble firearms and their components (Sait "Youtube", https://support.google.com/ youtube/answer/2802168?hl=uk).

Depending on the type of violation of YouTube channel usage rules, a user channel can be fully disabled, access to certain video may be removed, Google account or access of Google account to the service in general or to its part for a certain period (for example, up to 90 days) can be terminated (Sait "Youtube", https://www.youtube.com/t/terms).
Facebook. Facebook administration terminates accounts of users who violate official site rules. Facebook as well as other social media have certain conditions for using the capacity. The person who registers his/her account (page) agrees with the established rules, so he/ she is obliged to fulfil them. In addition, such person confirms his/her agreement to terminate the page in case of violations. The grounds for the content termination on Facebook by employees of the operative units of the National Police of Ukraine are:

- a real risk of physical harm or direct threat to public security;

- presence of conditional threats of terrorists and other persons who committed violence;

- the involvement of a person in a criminal organization or in committing crimes such as terrorism, organized hatred, mass murder (including attempt) or serial murder, human trafficking, organized violence or criminal activities; - encouragement certain criminal or harmful actions directed against people, companies, property or animals, as well as organization and promotion of such actions or recognition of their commission;

- publication by private individuals or producers, even official, of information about the circulation of narcotic drugs, psychotropic substances, precursors, as well as medical (psychotropic) drugs, firearms, their parts and ammunition, except for cases of advertising of firearms on condition of compliance with all applicable laws and legal provisions;

- fraud against other users to seize money or property (Sait "Facebook", https://uk-ua. facebook.com/terms).

Depending on the type and gravity of violation of Facebook rules, the account may be terminated completely or for a certain period - from a day to several months.

At the same time, the termination of prohibited accounts by operational units of the National Police of Ukraine requires solving problems, such as:

- the legality of the creation and use of anonymous accounts (accounting records) by operational units of the National Police of Ukraine, enabling with encryption of affiliation to the law-enforcement body to detect and prevent criminal offenses, including the termination of spreading and disabling prohibited content, and also to record the traces in case of such criminal offense:

- the above measures shall be carried out by operational units of the National Police of Ukraine without the decryption of account and the IP address affiliation to the law enforcement agency or persons working in it.

Therefore, today, it is required to introduce and legislate an investigative measure, such as a computer intervention, enabling operational units of the National Police of Ukraine to 
implement effectively the measures to prevent and combat crime committed on the Internet.

4. Conclusions

To conclude, no defined grounds currently exist in the legal regulations to stop the distribution and termination of prohibited content, including by operational units. This deters law enforcement agencies from legal activities aimed at preventing and combating criminal offenses committed on the Internet. Therefore, it is proposed to introduce an investigative measure such as a computer intervention, thanks to which operational units of the National Police of Ukraine can carry out measures on covert detection, prevention of criminal offense, and also to record the traces in case of its commission. The above should find its reflection by adding paragraph 72 to part 1 of Article 8 of the Law of Ukraine "On operational and investigative activities", which should be stated as follows: "to conduct computer interference to detect and prevent criminal offenses, including stopping the spread and termination of prohibited and restricted content, and to record the traces in case of commission of a criminal".

\section{References:}

Ofitsiinyi sait Kiberpolitsii Ukrainy [Official site of the Cyberpolice of Ukraine] (2021). cyberpolice.gov. ua. Retrieved from: https://cyberpolice.gov.ua/news/u--roczi-do-kiberpolicziyi-nadijshlo-ponad--tysyachzvernen-shhodo-shaxrajstva-v-interneti-8412/ (in Ukrainian)

Ofitsiinyi sait Ukrainskoi mizhbankivskoi asotsiatsiia chleniv platizhnykh system YeMA [Official site of the Ukrainian Interbank Association of Members of EMA Payment Systems] (2021). ema.com.ua. Retrieved from: https://www.ema.com.ua/business/antifraud-hub/mobilecheck/ (in Ukrainian).

Pro avtorske pravo i sumizhni prava: Zakon Ukrainy vid 23 hrudnia 1993 r. № 3792-XII [On Copyright and Related Rights: Law of Ukraine of December 231993 № 3792-XII] (1993). zakon2.rada.gov.ua. Retrieved from: https://zakon.rada.gov.ua/laws/show/3792-12\#Text (in Ukrainian).

Pro Natsionalnu politsiiu: Zakon Ukrainy vid 2 lypnia 2015 r. [On the National Police: Law of Ukraine of July 2 2015] (2015). Vidomosti Verkhovnoi Rady Ukrainy - Information of the Verkhovna Rada of Ukraine, no. 40-41, art. 379 (in Ukrainian).

Pro operatyvno-rozshukovu diialnist: Zakon Ukrainy vid 18 liutoho 1992 r. № 2135-XII [On operational and investigative activities: Law of Ukraine of February 181992 № 2135-XII] (1992). zakon2.rada.gov.ua. Retrieved from: http://zakon2.rada.gov.ua/laws/show/2135-12 (in Ukrainian).

Pro sanktsii: Zakon Ukrainy vid 14 serpnia 2014 roku № 1644-VII [On Sanctions: Law of Ukraine of August 142014 № 1644-VII] (2014). Vidomosti Verkhovnoi Rady Ukrainy - Information of the Verkhovna Rada of Ukraine, no. 40, art. 2018 (in Ukrainian).

Pro telekomunikatsii: Zakon Ukrainy vid 18 lystopada 2003 r. № 1280-IV [On Telecommunications: Law of Ukraine of November 182003 № 1280-IV] (2015). Vidomosti Verkhovnoi Rady Ukrainy - Information of the Verkhovna Rada of Ukraine, no. 40-41, art. 379 (in Ukrainian)

Pro zastosuvannia personalnykh, spetsialnykh, ekonomichnykh ta inshykh obmezhuvalnykh zakhodiv (sanktsii): Ukaz Prezydenta Ukrainy vid 17 travnia 2017 r. № 133/2017 [On the application of personal, special, economic and other restrictive measures (sanctions): Decree of the President of Ukraine of May 172017 № 133/2017] (2017). president.gov.ua Retrieved from: https:/www.president.gov.ua/ documents/1332017-21850 (in Ukrainian).

Sait "Facebook" [Website "Facebook"].facebook.com. Retrieved from: https://uk-ua.facebook.com/terms (in Ukrainian).

Sait "Insta-helper" [Website "Insta-helper"]. insta-helper.com. Retrieved from: https://insta-helper.com/ ua/jak-poskarzhitisja-na-akkaunt-v-instagram-i-jak/ (in Ukrainian).

Sait "Kagutech" [Website"Kagutech"].kagutech.com. Retrieved from:https://ukr.kagutech.com/3897557blocked-account-in-quotinstagramquot-the-reasons-ways-to-unlock (in Ukrainian).

Sait "Ministerstva vnutrishnikh sprav Ukrainy" [Website of the Ministry of Internal Affairs of Ukraine] (2020). mvs.gov.ua. Retrieved from: https://osvita.mvs.gov.ua/news/pidsumki-roboti-chat-botu-stopnarkotikza-rik (in Ukrainian).

Sait "Mydovidka" [Website "Mydovidka"]. mydovidka.com. Retrieved from: https://mydovidka.com/ instagram/yak-napisati-v-instagram-skargu-yak-poskarzhitisya-na-foto-i-profil-shhob-jogo-zablokuvaliskilki-potribno-skarg-shhob-zablokuvali (in Ukrainian).

Sait "Mydovidka" [Website "Mydovidka"]. mydovidka.com. Retrieved from: https://mydovidka.com/ instagram/yak-poskarzhitisya-na-storinku-v-instagrame-shhob-zablokuvali-nazavzhdihttps://mydovidka. com/instagram/yak-poskarzhitisya-na-storinku-v-instagrame-shhob-zablokuvali-nazavzhdi (in Ukrainian).

Sait “Telegram" [Website "Telegram"]. telegram.org. Retrieved from: https://telegramfag.ru/kakpozhalovatsya-v-telegramme (in Russian).

Sait “Telegram” [Website "Telegram"].telegram.org. Retrieved from: https://t.me/stopdrugsbot (in Russian).

Sait "Vidpoviday.com" [Website "Vidpoviday.com"] vidpoviday.com. Retrieved from: http://vidpoviday. com/iak-zablokuvaty-chuzhyj-instagram-akkaunt-cherez-telefon-abo-kompiuter (in Ukrainian).

Sait "Youtube" [Website "Youtube"]. youtube.com. Retrieved from: https://www.youtube.com/ howyoutubeworks/policies/community-guidelines/\#community-guidelines (in Ukrainian).

Sait "Youtube" [Website "Youtube"]. youtube.com. Retrieved from: https://support.google.com/youtube answer/2802168?hl=uk (in Ukrainian) 
Sait "Youtube" [Website "Youtube"]. youtube.com. Retrieved from: https://www.youtube.com/t/terms (in Ukrainian).

Sait Multymediinoi platformy inomovlennia Ukrainy “Ukrinform” [Website of the Multimedia Platform of Foreign Broadcasting of Ukraine "Ukrinform"] (2020). ukrinform.ua. Retrieved from: https://www. ukrinform.ua/rubric-society/2857277-catbot-u-telegram-dopomig-zablokuvati-vze-ponad-300-narkoadres. html (in Ukrainian).

Striltsiv, O.M., Kryzhna, V.V., Maksymenko, O.V. (2014). Osoblyvosti rozsliduvannia kryminalnykh pravoporushen, poviazanykh iz rozpovsiudzhenniam u merezhi Internet zaboronenoho kontentu [Features of the investigation of criminal offenses related to the distribution of prohibited content on the Internet]. Kyiv: Nats. akad. vnutr. sprav (in Ukrainian).

\section{Олег Тарасенко,}

кандидат юридичних наук, доцент, доцент кафедри оперативно-розшукової діяльності, Начіональна академія внутрішніх справ, площа Солом'янська, 1, Київ, Україна, індекс 03035, OlehTarasenko@ukr.net

ORCID: orcid.org/0000-0002-3179-0143

\section{Олександр Стрільців,}

кандидат юридичних наук, старший науковий співробітник, уповноважений з антикорупиійної діяльності, Національна академія внутрішніх справ, площа Солом'янська, 1, Київ, Україна, індекс 03035, OleksandrStriltsiv@ukr.net

ORCID: orcid.org/0000-0002-8324-3053

\section{НЕОБХІДНІСТЬ ПРАВОВОГО ВРЕГУЛЮВАННЯ ВПРОВАДЖЕННЯ КОМП'ЮТЕРНОГО ВТРУЧАННЯ ЯК НОВОГО ОПЕРАТИВНО-РОЗШУКОВОГО ЗАХОДУ ОПЕРАТИВНИХ ПІДРОЗДІЛІВ}

Анотація. Ажтуальність статmі полягає в тому, що поширення злочинності в мережі Інтернет найбільш динамічна на сьогодні група суспільно-небезпечних діянь, яка прогресує у світі загалом і в Україні зокрема, набираючи найбільш небезпечних обертів. Це зумовлене поширенням автоматизації, інформатизації та комп'ютеризації всіх сфер життя, розвитком науки, стрімким розширенням сфери застосування інформаційних технологій. Водночас зростають негативні аспекти -інформаційні технології починають використовуватися у протиправних цілях, як наслідок, відбуваються якісні й кількісні зміни кіберзлочинності, яка набуває дедалі більш професійного, організованого та витонченого характеру. Результати. У статті вказано на відсутність законодавчо визначених можливостей оперативних підрозділів Національної поліції України реалізовувати завдання щодо виявлення кримінальних правопорушень, які вчиняються в мережі Інтернет, та запобігання їм, у тому числі з припинення поширення та блокування забороненого й обмеженого до обігу контенту, а також фіксувати сліди в разі вчинення таких кримінальних правопорушень. Висновки. На підставі визначених способів блокування та обмеження обігу забороненого чи обмеженого до обігу контенту в соціальних мережах і відеохостингу робиться висновок про необхідність запровадження нового оперативнорозшукового заходу - комп'ютерного втручання. Надаються пропозиції з внесення змін до Закону України «Про оперативно-розшукову діяльність» щодо нормативного врегулювання запропонованого нового оперативно-розшукового заходу. Підкреслюється, що проведення вказаних вище заходів оперативними підрозділами Національної поліції України має здійснюватися без розшифровування належності акаунту та IP-адреси до правоохоронного органу чи осіб, які в ньому працюють. Зроблено висновок, що на сьогодні в нормативно-правових актах відсутні визначені підстави для припинення поширення та блокування забороненого контенту, зокрема й оперативними підрозділами. Вказане не дає змоги правоохоронним органам здійснювати в законодавчо визначеному полі діяльність, спрямовану на запобігання кримінальним правопорушенням, що вчиняються в мережі Інтернет, та протидії їм. У зв'язку з викладеним пропонується запровадити такий оперативно-розшуковий захід, як комп'ютерне втручання, завдяки якому оперативні підрозділи Національної поліції України можуть здійснювати заходи 3 негласного виявлення такого кримінального правопорушення, запобігання йому, а також фіксувати сліди в разі його вчинення.

Ключові слова: комп'ютерне втручання, оперативно-розшуковий захід, заборонений контент, оперативні підрозділи, кримінальні правопорушення, мережа Інтернет. 